\title{
The effect of a SECoS in crude palm oil forecasting to improve business intelligence
}

\author{
Al-Khowarizmi ${ }^{1}$, Ilham Ramadhan Nasution ${ }^{2}$, Muharman Lubis ${ }^{3}$, Arif Ridho Lubis ${ }^{4}$ \\ ${ }^{1}$ Department of Information Technology, Universitas Muhammadiyah Sumatera Utara, Indonesia \\ ${ }^{2}$ Department of Accounting, Universitas Medan Area, Indonesia \\ ${ }^{3}$ School of Industrial Engineering, Telkom University, Indonesia \\ ${ }^{4}$ Department of Computer Engineering and Informatics, Politeknik Negeri Medan, Indonesia
}

\begin{tabular}{l}
\hline \hline Article Info \\
\hline Article history: \\
Received Feb 5, 2020 \\
Revised Mar 23, 2020 \\
Accepted Apr 6, 2019 \\
\hline
\end{tabular}

Keywords:

ANN

Business intelligence

Crude palm oil

e-Commerce

SECoS

\begin{abstract}
Crude palm oil is a crop that has a harvest period of \pm 2 weeks and is in dire need of dissemination of information using e-commerce in order to be able to predict the price of the yield of companies or individual gardens within the next 2 weeks in order to improve studies on business intelligence. The disadvantage of not implementing e-commerce is certainly detrimental to the garden owner because they have to go through an agent so prices are set based on the agent. So with the application of e-commerce, buyers of crude palm oil can predict prices in conducting business processes to the future. So the need to forecasting the price of crude palm oil heads in order to improve the application of business intelligence using the evolution-based artificial neural network (ANN) method which in this paper is tested with SECoS get a MAPE value of $0.035 \%$ and by applying business intelligence can protect transaction costs by $33.3 \%$.
\end{abstract}

This is an open access article under the CC BY-SA license.

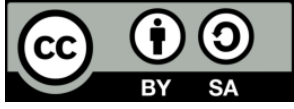

\section{Corresponding Author:}

Al-Khowarizmi,

Faculty of Computer Science and Information Technology,

Universitas Muhammadiyah Sumatera Utara,

Jalan Kapten Muhktar Basri No 3 Medan, Sumatera Utara, Indonesia.

Email: alkhowarizmi@umsu.ac.id

\section{INTRODUCTION}

Information technology has made it easy for humans in their daily activities and activities in their role as automation technology [1]. So that information technology until now increasingly brings enormous benefits in managing data and information [2]. In general, an agency must be supported by services resulting from the development of information technology [3, 4]. Electronic commerce (e-Commerce) is the result of the development of information technology that is specialized in the business process of selling, purchasing or exchanging products, services and exchanging information through the internet network [5]. Besides e-commerce is also part of e-business, where the scope of e-business is broader, not only commercial but also includes business partners and customer service [6]. So that data transacted through e-commerce is able to float the process of big data with this the creation of business intelligence [7].

Crude palm oil is one of the types of business in estate crops which occupies an important position in the agricultural sector. This is because of the many plants that produce oil or fat, palm oil which produces the largest economic value per hectare in the world $[8,9]$. In the process of harvesting, oil palm has a harvest period of \pm 2 weeks [10]. Reference [11] explained that in the business process, harvesting oil palm, both company and individual, sells palm to the palm oil agent and the agent sells the palm oil processing, in this case the palm oil mill. Reference [12] also asserted that the process of selling and buying depends on 
the price that the agent submits to the plantation owner can lead to a monopoly on the price of oil palm for which an information system is needed.

So by implementing e-commerce in the business process of buying and selling palm oil will change all marketing activities and also at the same time cut operational costs for trading activities and at the same time will create business to business (B2B) $[13,14]$. In government, the B2B process that is most often found is tender tendering, which is using the LPSE application [15]. Reference [16] has developed the e-commerce process by utilizing cooperative principles to become the basis for developing business intelligence (BI). Reference [17] promoting BI is increasingly popular and important in an organization or company. BI strongly supports the progress of companies from various sectors including the SME sector [18]. BI began to be conceptualized from the 1990s but (BI) was introduced in the early 1990s where the use of mobile phones was prevalent in the community.

However, the concept was not adopted by users because of technology and cultural barriers at that time until the emergence of smart devices such as smartphones and tablets drew people's attention to the advantages of cellular BI [19]. BI is closely related to big data, so that BI continues to be researched in order to portray its role as data science and prepare for the optimization of big data in the future [20, 21]. For this reason, BI must be supported by a number of (ANN) techniques where one of the appropriate methods in forecasting is the simple evolving connectionist system (SECoS) or evolving multi-layer perceptron method which is a minimal implementation of the principle of evolving connectionist systems (ECoS) [22, 23]. SECoS is very suitable because it has been meticulously by reference [22] by doing big data forecasting by using SECoS and the results received are very good with gold price forecasting data.

\section{RESEARCH METHOD}

\subsection{Dataset}

The used datasets in this paper are daily CPO price, oil price, inflation rate, and US Dollar index. The data sets are recorded during the period of August $1^{\text {st }} 2019$ to September $12^{\text {th }} 2019$. Training data-set is set from August $1^{\text {st }} 2019$ to August $2^{\text {th }} 2019$ and testing data-set is set from August 30 2019 to September $12^{\text {th }} 2019$. The data were obtained from world crude palm oil futures council website: www.investing.com.

\subsection{Simple evolving connectionist systems (SECoS)}

SECoS is a minimalist implementation of the ECoS principle which is often also called simple evolving MLP (multilayer perceptron). SECoS consists of three neuron layers [22, 24]. The first layer is an input layer with linear or other transfer functions. The second layer, the hidden layer is the evolving layer, and the third neuron layer is the output layer. In the linear activation function is used, and then the activation of $\mathrm{A}$ in the evolving node $\mathrm{n}$ layer is determined by:

$$
A_{n}=1-D_{n}
$$

where $A_{n}$ is the activation value at node $n$ and $D_{n}$ is the normalized distance value between the input vector and then coming weight vector at that node. What $\mathrm{D}_{\mathrm{n}}$ distance value is generally calculated using normalized Hamming distance:

$$
D_{n}=\frac{\sum_{\mathbb{i}}^{K}\left|I_{i}-W_{i}\right|}{\sum_{i \mathfrak{i}}^{K}\left|I_{i}+W_{i}\right|}
$$

where $\mathrm{K}$ is the number of input nodes in SECoS, is the input vector, and $\mathrm{W}$ is the input weight matrix in the evolving layer. Furthermore, learning is done by the SECoS method on the crude palm oil price data. The SECoS algorithm is as follows [25]:

- Propagate input vector I into the network

- If the maximum activation $\left(\mathrm{A}_{\max }\right)$ of the node is smaller than the sensitivity threshold coefficient $\left(\mathrm{S}_{\mathrm{thr}}\right)$, then:

Add a new node

If not:

a. Calculate the error value between learning out comes (output vector $\mathrm{O}_{c}$ ) and actual values (output vector $\mathrm{O}_{\mathrm{d}}$ ).

b. If the error value is greater than the error threshold coefficient $\left(E_{t r h}\right)$ or the desired output node is not active, then:

Add a new node

If not:

Make changes in connection weights on the winning hidden node.

- Repeat the steps for each input vector

The effect of a SECoS in crude palm oil forecasting to improve business intelligence (Al-Khowarizmi) 
When a node is added, the input weight is initialized according to the input vector I and the output weight is initialized according to the $\mathrm{O}_{\mathrm{d}}$ vector output. The propagation process from the hidden layer to the output layer can be done in two ways. The first method with the One-of-N propagation method is that propagation is only done by the hidden node with the highest activation value. The second method is done by the Many-of-N propagation method, that is, propagation is only done by hidden nodes that have an activation value above the activation threshold. Modification of incoming weights on winning node $j$ is done according to the following equation:

$\mathrm{WWii}_{s} \mathrm{j}(\mathrm{tt}+1)=\mathrm{WWii}_{s} \mathrm{jj}(\mathrm{tt})+\eta \mathrm{I}^{1} \mathrm{IIi}-\mathrm{WWii}_{s} \mathrm{j}(\mathrm{tt})$

where:

- $W W_{i i, j j}(t t)$ is the entry weightii, jj at $(t t)$

- $W W_{i i, j j}(t t+1)$ is the entry weight $i i, j j$ at $(t t+1)$

- $\eta \eta_{1}$ is learning rate 1

- $I I_{i i}$ is the component- $i$ at input vector $I$

While the weight modification comes out of node $j$ following equation:

$$
W_{W j} \cdot p p(t t+1)=W W_{j j} \cdot p p(t t)+\eta \eta^{2 A A j j} \times E E p p
$$

where:

- $W W_{j j, p p}(t t)$ is the out weight jj, pp at (tt)

- $W W_{j j, p p}(t t+1)$ is the out weight $j j, p p$ at $(t t+1)$

- $\eta \eta_{2}$ is learning rate 2

- $A A_{j j}$ is activation value from node

\subsection{General architecture}

In general architecture is illustrated by applying the diagram and how it looks in Figure 1.

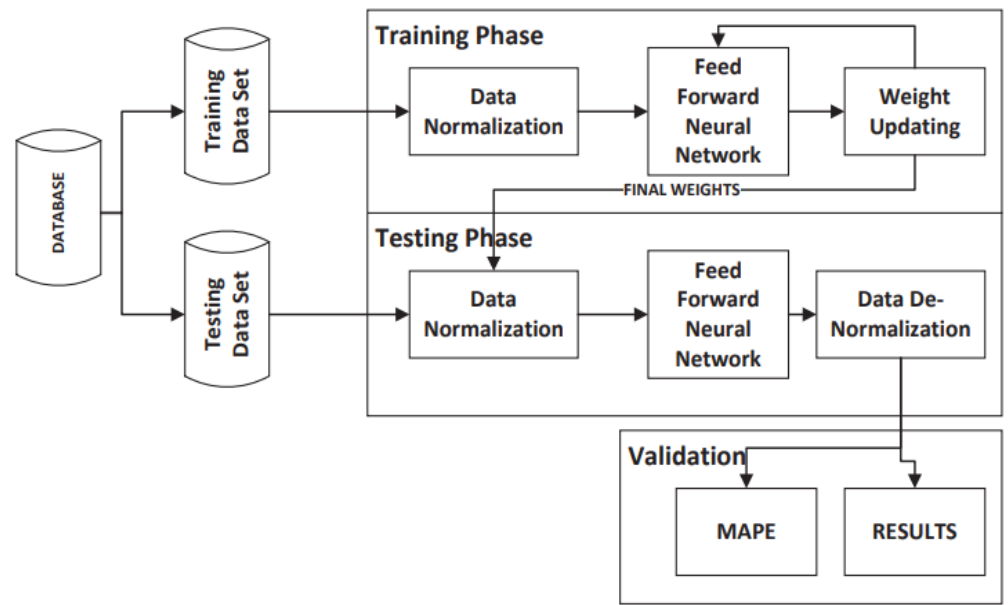

Figure 1. General architecture

Explanation from step Figure 1 as follows:

- Input parameter values such as learning rate which at this stage will be compared with adaptive learning, error threshold, and sensitivity threshold.

- Before conducting the data process, the data to be trained is normalized so that the data to be processed has a range from 0 to 1 with (5);

$$
y=\frac{x-x_{\min }}{x_{\max }-x_{\min }}
$$

where:

$x=$ CPO price value 


$$
\begin{array}{ll}
y & =\text { Normalization value } \\
x_{\min } & =\text { Minimum value CPO price } \\
x_{\max } & =\text { Maximal values CPO price }
\end{array}
$$

- Make the first layer and its node $\left(r_{1}\right)$ and initialize the $\mathrm{W}_{\mathrm{i}}$ input weight, 1 according to input vector I and output weight $\mathrm{W}_{1}, \mathrm{p}$ according to $\mathrm{O}_{\mathrm{d}}$ vector output.

- Calculate the activation value by involving the normalized hamming distance formula for each node that exists with (1) and (2) and continued with SECoS calculation.

a. Look for nodes in the evolving layer that have activation value greater than the sensitivity threshold parameter.

b. If there is a node that has an activation value greater than the sensitivity threshold parameter, then propagate the data to the output layer. If it doesn't exist, then create a new node as in step 4.

c. Calculate the error value from the output layer. If the error value is greater than the error threshold parameter, then create a new node and return to step 4. If the error value is smaller than the error threshold parameter, then change the weight value according to (3) and (4).

- In data training, do steps 1 to 4.

- Find the node that has the highest activation value and propagate the data to the output layer through that node.

- Calculate the magnitude of the error using MAPE (mean absolute percentage error) with the following (6).

$$
\text { MAPE }=\frac{\sum_{t=1}^{n}\left|\frac{Q-b}{a}\right|}{n} \times 100 \%
$$

where:

$$
\begin{aligned}
& a=\text { actual data } \\
& b=\text { result data } \\
& n=\text { lots of data }
\end{aligned}
$$

\section{RESULTS AND DISCUSSION}

\subsection{Forecasting process}

Data were analyzed to make it possible to predict big data by SECoS on the price of crude palm oil. The analysis, of course, requires several tools to help the process of calculating the SECoS method. As a result, the process of providing output is that it requires the SECoS method time in training and testing data in order to get the results of big data predictions. In making forecasting using SECoS, first determine the value of the parameter to be used. The parameter values that will be used are learning rate $1=0.9$, learning rate $2=0.6$, sensitivity threshold $=0.99$, error threshold $=0.1$, and input price data 1 day before the data to be predicted. Normalize the data contained in Table 1 based on (5). Furthermore, forming a vector of data, that will be used as input and output in the prediction process. The input used is the CPO price one day before the date to be predicted. This data vector can be seen in Table 2.

Table 1. Data normalization value

\begin{tabular}{clcc}
\hline No. & \multicolumn{1}{c}{ Date } & Price & $\begin{array}{c}\text { Normalization } \\
\text { value }\end{array}$ \\
\hline 1. & August 1st 2019 & 514 & 0 \\
2. & August 2nd 2019 & 518 & 0.083333333 \\
3. & August 5th 2019 & 526 & 0.25 \\
4. & August 6th 2019 & 526 & 0.25 \\
5. & August 7th 2019 & 528 & 0.291666667 \\
6. & August 8th 2019 & 534 & 0.416666667 \\
7. & August 9th 2019 & 544 & 0.625 \\
8. & August12th2019 & 549 & 0.729166667 \\
9. & August13th2019 & 548 & 0.708333333 \\
10. & August14th2019 & 554 & 0.833333333 \\
11. & August16th2019 & 548 & 0.708333333 \\
12. & August19th2019 & 537 & 0.479166667 \\
13. & August20th2019 & 540 & 0.541666667 \\
14. & August 21st2019 & 550 & 0.75 \\
15. & August 22nd 2019 & 557 & 0.895833333 \\
16. & August 23rd 2019 & 555 & 0.854166667 \\
17. & August26th2019 & 562 & 1 \\
18. & August27th2019 & 555 & 0.854166667 \\
19. & August28th2019 & 556 & 0.875 \\
20. & August29th2019 & 553 & 0.8125 \\
\hline
\end{tabular}

Table 2. Data vector

\begin{tabular}{ccl}
\hline Input & $\begin{array}{c}\text { Forecasting } \\
\text { target }\end{array}$ & $\begin{array}{c}\text { Date of forecasting } \\
\text { target }\end{array}$ \\
\hline 0 & 0.083333333 & August 1st 2019 \\
0.083333333 & 0.25 & August 2nd 2019 \\
0.25 & 0.25 & August 5th 2019 \\
0.25 & 0.291666667 & August 6th 2019 \\
0.291666667 & 0.416666667 & August 7th 2019 \\
0.416666667 & 0.625 & August 8th 2019 \\
0.625 & 0.729166667 & August 9th 2019 \\
0.729166667 & 0.708333333 & August 12th 2019 \\
0.708333333 & 0.833333333 & August 13th 2019 \\
0.833333333 & 0.708333333 & August 14th 2019 \\
0.708333333 & 0.479166667 & August 16th 2019 \\
0.479166667 & 0.541666667 & August 19th 2019 \\
0.541666667 & 0.75 & August 20th 2019 \\
0.75 & 0.895833333 & August 21st 2019 \\
0.895833333 & 0.854166667 & August 22nd 2019 \\
0.854166667 & 1 & August 23rd 2019 \\
1 & 0.854166667 & August 26th 2019 \\
0.854166667 & 0.875 & August 27th 2019 \\
0.875 & 0.8125 & August 28th 2019 \\
0.8125 & 0 & August 29th 2019 \\
\hline
\end{tabular}


After doing the vector data, weights W1 and W2. The first input-output vector pair is used as an initial weight so that $\mathrm{W} 1=0$ and $\mathrm{W} 2=0.083333333$ conduct training data. The data used for training ranges from August $1^{\text {st }} 2019$ to August $29^{\text {th }} 2019$. Data used for the testing process ranges from August $30^{\text {th }} 2019$ to September $12^{\text {th }}$ 2019. The results of this process can be seen in Table 3. Furthermore, the denormalization process is carried out to change the forecasting results in Table 3 to the actual values. The results of denormalization can be seen in Table 4. Calculate the average error value of the forecasting results in Table 4 using (3) and (4). MAPE value generated is equal to $0.035 \%$ and the number of hidden nodes produced is 16 data.

Table 3. Forecasting data results

\begin{tabular}{clcc}
\hline No. & \multicolumn{1}{c}{ Date } & Target & Forecasting data results \\
\hline 1. & August 30th 2019 & 0 & 0.1 \\
2. & August 31th 2019 & 0.05303 & 0.06 \\
3. & September 3rd 2019 & 0.560606 & 0.57 \\
4. & September 4th 2019 & 0.969697 & 1 \\
5. & September 5th 2019 & 0.742424 & 0.75 \\
6. & September 6th 2019 & 1 & 1 \\
7. & September 7th 2019 & 0.568182 & 0.55 \\
8. & September 10th 2019 & 0.954545 & 1 \\
9. & September 11th2019 & 0.954545 & 1 \\
10. & September 12th 2019 & 0.386364 & 0.4 \\
\hline
\end{tabular}

Table 4. Results of forecasting data normalization

\begin{tabular}{clccc}
\hline No. & \multicolumn{1}{c}{ Date } & Target & Forecasting data results & Error \\
\hline 1. & August 30th 2019 & 593.3 & 580 & 0.1 \\
2. & August 31th 2019 & 594 & 525 & 0.00697 \\
3. & September 3rd 2019 & 600.7 & 590.8001 & 0.009394 \\
4. & September 4th 2019 & 606.1 & 587.7333 & 0.030303 \\
5. & September 5th 2019 & 603.1 & 597.0081 & 0.007576 \\
6. & September 6th 2019 & 606.5 & 606.5 & 0 \\
7. & September 7th 2019 & 600.8 & 620.6612 & -0.01818 \\
8. & September 10th 2019 & 605.9 & 578.3591 & 0.045455 \\
9. & September 11th2019 & 605.9 & 578.3591 & 0.045455 \\
10. & September 12th 2019 & 598.4 & 578 & 0.013636 \\
\hline
\end{tabular}

\subsection{BI application}

The application of BI will change all marketing activities and at the same time cut operational costs for trading activities and at the same time be able to create application-based business to business (B2B). The owners of private oil palm plantations can market their crops to online media so that palm oil processing companies can make purchases online. This can increase the income of oil palm plantation owners. In addition, for crude palm oil plantation companies that have an area of $<=10,000$ ha or do not have processing, the results are sold to the mill, within 2 weeks, they can market or sell to the application so that buyers place an order online so as to eliminate the formation of the committee tenders and reduce the budget or burden of crude palm oil plantation companies. The application of BI can be seen in the Figure 2.

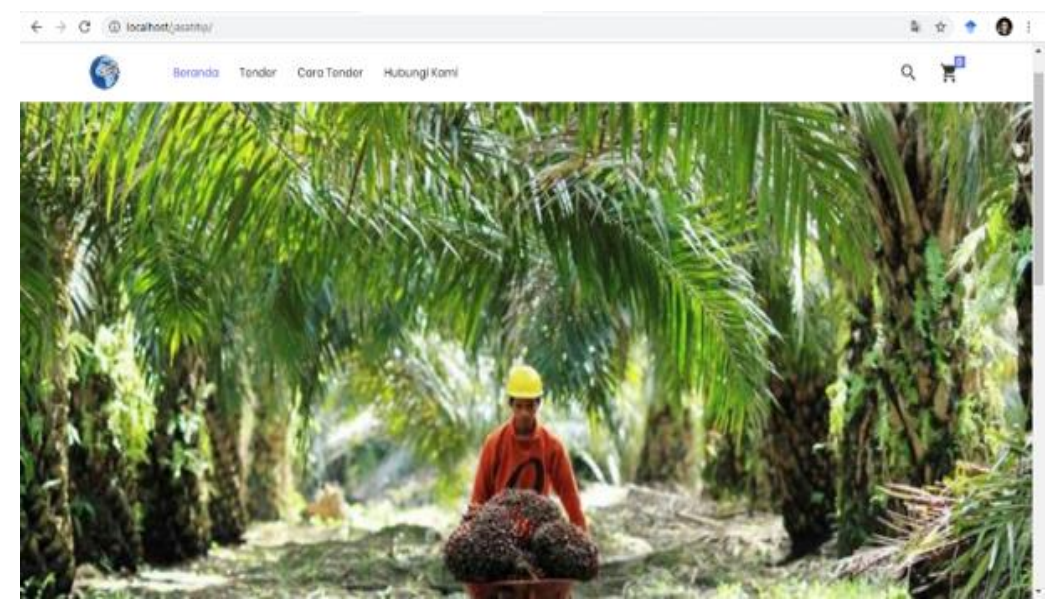

Figure 2. Main display 
Figure 2 can be seen that the initial appearance of e-commerce where crude palm oil plantations, both companies and individuals, can purchase and register accounts. Then the account is divided into 2 namely crude palm oil sellers and crude palm oil buyers. After that the seller gives his palm oil data so that buyers can see and bid through the application. Figure 3 shows the appearance of the oil palm being sold.
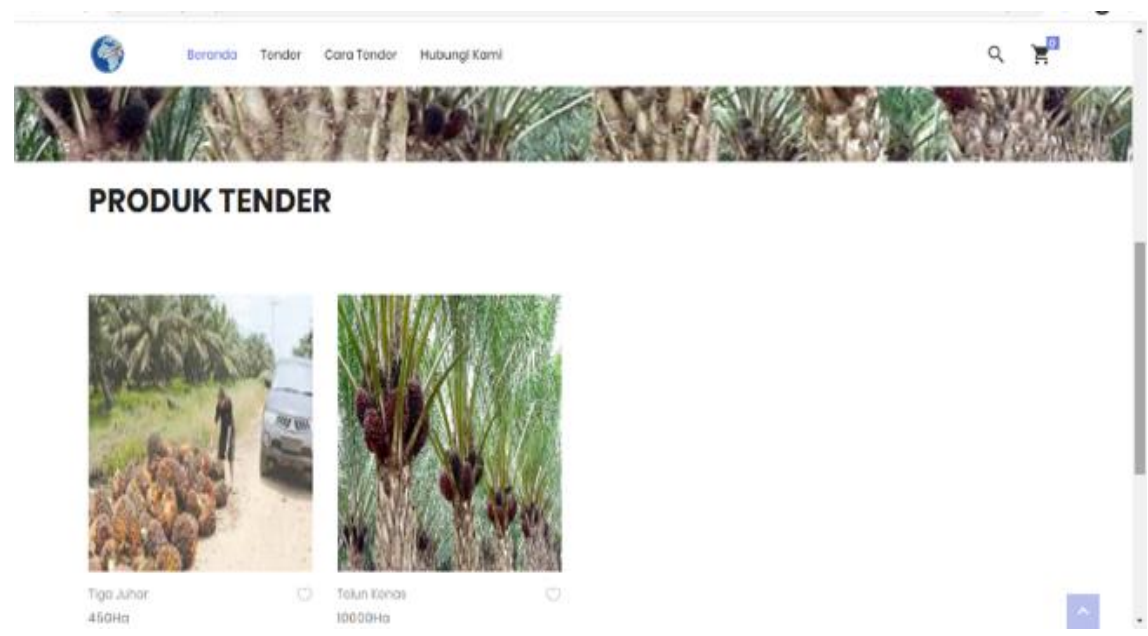

Figure 3. Display of system tender

Figure 3, it can be seen that what is being sold can directly make the bidding process. So with this application the addition of the income of the palm oil owner is simulated in Table 1, world palm prices in IDR $1,500 / \mathrm{kg}$, while agents accommodate prices of IDR $1,000 / \mathrm{kg}$. From Table 5 it is explained that if the seller and buyer of crude palm oil weighing in the palm weight (tons) column has the advantage of saving cost. So with the application by implementing this BI will be able to increase the income of oil palm plantation owners by $33.3 \%$ in each harvest.

Table 5. Simulation of benefits

\begin{tabular}{ccccc}
\hline $\begin{array}{c}\text { Palm weight } \\
\text { (tons) }\end{array}$ & $\begin{array}{c}\text { Total world } \\
\text { prices }\end{array}$ & $\begin{array}{c}\text { Total agent } \\
\text { container prices }\end{array}$ & Saved costs & $\%$ \\
\hline 10 & 13607775 & 9071850 & 4535925 & 33,3 \\
100 & 136077750 & 90718500 & 45359250 & 33,3 \\
1.000 & 1360777500 & 907185000 & 453592500 & 33,3 \\
10.000 & 13607775000 & 9071850000 & 4535925000 & 33,3 \\
\hline
\end{tabular}

\section{CONCLUSION}

In summary, this paper implements e-commerce by maximizing the B2B process and developing a Business Intelligence Model that is specific to the application-based business revenue of crude palm oil plantations which is able to increase the income of oil palm plantations by $33.3 \%$ per harvest and is able to cut operational costs for oil palm trading activities. The application of BI can forecast the price of crude palm oil for the next 2 weeks using the ANN concept namely the SECoS method to get a MAPE of $0.035 \%$.

\section{ACKNOWLEDGEMENTS}

The author would like to thank the research Institute of the Universitas Muhammadiyah Sumatera Utara for supporting the dissemination of this research.

\section{REFERENCES}

[1] M. Ngafifi, "Technological advances and patterns of human life in a socio-cultural perspective," in Bahasa "Kemajuan teknologi dan pola hidup manusia dalam perspektif sosial budaya," Jurnal Pembangunan Pendidikan: Fondasi dan Aplikasi, vol. 2, no. 1, pp. 33-47, 2014. 
[2] G. Polla, "The role of information technology in the development of E-Learning at MIPA faculties in Indonesia," in Bahasa "Peranan teknologi informasi dalam pengembangan E-Learning pada fakultas MIPA di Indonesia," ComTech: Computer, Mathematics and Engineering Applications, vol. 1, no. 2, pp. 1025-1032, 2010.

[3] A. Aziz, "Utilization of information technology in postal business development," in Bahasa "Pemanfaatan teknologi informasi dalam pengembangan bisnis pos," Buletin Pos dan Telekomunikasi, vol. 10, no. 1, pp. 35-50, 2012.

[4] A. R. Lubis, S. Prayudani, M. Lubis, and Al-Kowarizmi, "Decision making in the tea leaves diseases detection using mamdani fuzzy inference method," Indonesian Journal of Electrical Engineering and Computer Science, vol. 12, no. 3, pp. 1273-1281, 2019.

[5] S. Kosasi, U. Kasma, and B. Susilo, "The mediating role of intention to use e-commerce adoption in MSMEs," 1st International Conference on Cybernetics and Intelligent System, vol. 1, pp. 29-34, 2019.

[6] E. A. Wibowo, "Utilization of E-Commerce technology in business processes," in Bahasa "Pemanfaatan teknologi E-Commerce dalam proses bisnis," EQUILIBIRIA, vol. 1, no. 1, pp. 95-108, 2016.

[7] A. R. Lubis, M. Lubis, Al-Khowarizmi, and D. Listriani, "Big data forecasting applied nearest neighbor method," International Conference on Sustainable Engineering and Creative Computing, pp. 116-120, 2019.

[8] S. H. Nasution, C. Hanum, and J. Ginting, "Growth of oil palm seedlings (Elaeis guineensis Jacq.) in various comparisons of solid decanter planting media and oil palm empty fruit bunches in a single stage system," in Bahasa "Pertumbuhan bibit kelapa sawit (Elaeis guineensis Jacq.) pada berbagai perbandingan media tanam solid decanter dan tandan kosong kelapa sawit pada sistem single stage," AGROEKOTEKNOLOGI, vol. 1, no. 2, pp. 691-701, 2014.

[9] Y. Fauzi, Y. Widyastuti, I. Setyawibawa, and R. Hartono, "Palm oil," in Bahasa "Kelapa sawit," Penebar Swadaya, Jakarta (ID), 2008

[10] M. S. Handini, "The effect of sludge on oil palm mills with different doses on the growth and yield of two varieties of soybean plants (Glycine max (L.) Merrill)," in Bahasa "Pengaruh pemberian sludge pabrik kelapa sawit dengan dosis yang berbeda terhadap pertumbuhan dan hasil dua varietas tanaman kedelai (Glycine max (L.) Merrill)," Doctoral Dissertation, Universitas Islam Negeri Sultan Sarif Kasim Riau, 2014.

[11] N. Nurhamlin and S. Aliyah, "The socio-economic relationship between oil palm farmers and palm oil tauke in the village of Petai Baru, Singi District, Kuantan District, Singi," in Bahasa "Hubungan sosial ekonomi antara petani sawit dengan tauke sawit di Desa Petai Baru, Kecamatan Singingi, Kabupaten Kuantan Singingi," Jurnal Online Mahasiswa Fakultas Ilmu Sosial dan Ilmu Politik Universitas Riau, vol. 2, no. 1, pp. 1-15, 2015.

[12] S. Sukri, S. Salamun, and W. Rahmalina, "Online palm oil tauke information system to avoid price monopolies in grandmother's senama village," in Bahasa "Sistem Informasi tauke sawit online untuk menghindari monopoli harga di desa senama nenek," Jurnal Pengabdian Masyarakat Multidisiplin, vol. 2, no. 2, pp. 97-108, 2018.

[13] D. Irmawati, "Utilization of e-commerce in the business world," in Bahasa "Pemanfaatan e-commerce dalam dunia bisnis," Jurnal Ilmiah Orasi Bisnis, vol. 6, pp. 95-112, 2011

[14] C. Sharma and A. Jain, "Entrepreneurship through Start-ups in hill areas using photovoltaic systems," Bulletin of Electrical Engineering and Informatics, vol. 6, no. 2, pp. 105-121, 2017

[15] H. P. Yuwinanto, "Implementation of E-Procurement in the Surabaya city government," in Bahasa "Implementasi E-Procurement pada pemerintah Kota Surabaya," Jejaring Administrasi Publik, vol. 5, no. 1, pp. 212-231, 2013.

[16] F. Fauzi, Al-Khowarizmi, and Muhathir, "The e-Business community model is used to improve communication between businesses by utilizing union principles," Journal Of Informatics And Telecommunication Engineering, vol. 3 , no. 2 , pp. 252-257, 2020.

[17] G. Hayardisi, K. B. Seminar, and A. Ramadhan, "Analysing signal strength and connection speed in cloud networks for enterprise business intelligence," TELKOMNIKA Telecommunication, Computing, Electronics and Control, vol. 16, no. 4, pp. 1779-1784, 2018.

[18] J. A. Becerra-Godinez, J. L. Serralde-Coloapa, M. S. Ulloa-Marquez, A. Gordillo-Mejia, and E. Acosta-Gonzaga, "Identifying the main factors involved in business intelligence implementation in SMEs," Bulletin of Electrical Engineering and Informatics, vol. 9, no. 1, pp. 304-310, 2020.

[19] L. Y. Fang, N. F. M. Azmi, Y. Yahya, H. Sarkan, N. N. A. Sjarif, and S. Chuprat, "Mobile business intelligence acceptance model for organisational decision making," Bulletin of Electrical Engineering and Informatics, vol. 7, no. 4, pp. 650-656, 2018.

[20] S. Manikam, S. Sahibudin, and V. Kasinathan, "Business intelligence addressing service quality for big data analytics in public sector," Indonesian Journal of Electrical Engineering and Computer Science, vol. 16, no. 1, pp. 491-499, 2019.

[21] A. R. Lubis, M. Lubis, and Al-Khowarizmi, "Optimization of distance formula in K-Nearest Neighbormethod," Bulletin of Electrical Engineering and Informatics, vol. 9, no. 1, pp. 326-338, 2020.

[22] Al-Khowarizmi, "Modify the SECoS method by using the distance formula," in Bahasa "Modifikasi metode SECoS dengan menggunakan rumus distance," Thesis, Universitas Sumatera Utara, 2017.

[23] Al-Khowarizmi, O. S. Sitompul, Suherman, and E. B. Nababan, "Measuring the accuracy of simple evolving connectionist system with varying distance formulas," Journal of Physics: Conference Series, vol. 930, no. 1, pp. 1-6, 2017.

[24] R. F. Rahmat, A. Rizki, A. F. Alharthi and R. Budiarto, "Big data forecasting using evolving multi-layer perceptron," 4th Saudi International Conference on Information Technology (Big Data Analysis, pp. 1-5, 2016.

[25] N. K. Kasabov, "Evolving connectionist systems for adaptive learning and knowledge discovery: Trends and directions," Knowledge-Based Systems, vol. 80, pp. 24-33, 2015. 


\section{BIOGRAPHIES OF AUTHORS}

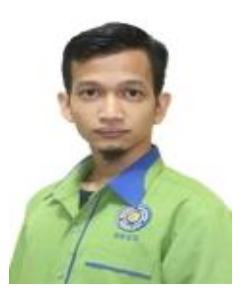

Al-Khowarizmi, M. Kom. was born in Medan,Indonesia, in 1992. He is a lecturer in Department of Information Technology-Faculty of Computer Science and Information Technology at Universitas Muhammadiyah Sumatera. He got master from University of Sumatera Utara in 2017 and graduate from Universitas Harapan Medan in 2014, both information system. His main research interest is data science, big data, machine learning, neural network, artificial intelligence and business intelligence.

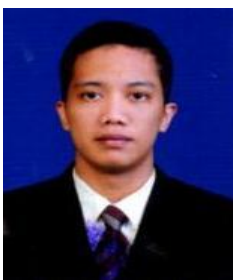

Ilham Ramadhan Nasution, S.E., Ak., M. Si., CA.was born in Banda Aceh, Indonesia in 1987. $\mathrm{He}$ is a lecturer in Department of Accounting-Faculty of Business and Administration at Universitas Medan Area. He got master from University of Sumatera Utara in 2013 and graduate from Universitas Islam Sumatera Utara Medan in 2009. His main research interest is Financial Accounting, Accounting Fraud, Data Science and business intelligence.

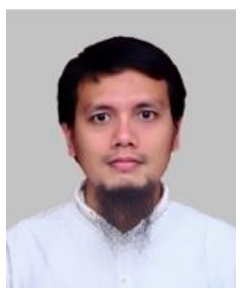

Muharman Lubis, Ph.D.IT. has finished his Doctoral degree recently in Information Technology at 2017 in International Islamic University Malaysia, he also received his Master degree from same university at 2011 and Bachelor degree from University Utara Malaysia at 2008, both in Information Technology. He joined as a Lecturer in the School of Industrial Engineering, Telkom University, in 2017. His research interests include privacy protection, information security awareness, knowledge management and project management.

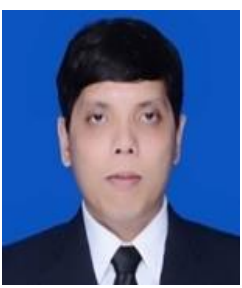

Arif Ridho Lubis, M.Sc.IT. is taking doctoral program at Universitas Sumatera Utara, he got master from University Utara Malysia in 2012 and graduate from University Utara Malaysia in 2011, both information technology. He is a lecturer in Department of Computer Engineering and Informatics, Politeknik Negeri Medan in 2015. His research interest includes computer science, network, science and project management. 